CERIF: S130

\author{
Dr. Miloš Živković*
}

\title{
ACQUISITION OF OWNERSHIP OF REAL PROPERTY BY CONTRACT IN SERBIAN LAW - DEPARTING FROM THE TITULUS-MODUS SYSTEM?
}

This paper examines the systems of contractual acquisition of ownership of real property in various civil law jurisdictions. It then presents Serbian legislative solutions in that respect, commonly denoted as titulus-modus system. It particularly emphasizes recent departures from the traditional system in respect of acquisition of ownership of real property in the current practice of Serbian courts and in recent legislation. These developments seem to indicate a certain shift towards a system of conveyance effect of the contract itself, resembling in some aspects the French law. This development is subjected to critical analysis, the conclusion of which is that there needs to be a consistent application of a chosen system, once it is chosen. Finally, the author proposes a solution that would achieve such goal and increase the level of legal certainty.

Key words: $\quad$ Acquisition of Real Property. - Iustus titulus. - Modus acquirendi.

\section{INTRODUCTION}

The rules of acquisition of ownership differ in various legal systems of civilian (continental) tradition. Understanding these differences, which are quite significant from the doctrinal point of view, is an excellent exercise for better understanding of each particular national system. Therefore Serbian textbooks on Property, while explaining the system adopted in Serbia, usually make a short reference to other existing systems. ${ }^{1}$ The purpose is to get a better understanding of the domestic law, naturally, and not to go deep into comparative analysis.

* Assistant Professor, University of Belgrade Faculty of Law, mdz@ius.bg.ac.rs.

1 See instead of many O. Stanković, M. Orlić, Stvarno pravo [Property Law], Belgrade $1999^{9} 71-73$. Even the pre-World War II textbooks employed this approach, see 
This paper will follow a similar structure: first, the relevant competing systems of real property ownership acquisition by means of contract within the civil law tradition willbe presented in brief, thereafter the paper will examine the system currently in existence in Serbia, followed by examination of circumstances in which Serbian case law and special legislation depart from such doctrinal solution. These deviations will be scrutinized from both theoretical and practical points of view, with certain suggestions for improvement and resolution of problematic issues.

\section{SYSTEMS OF OWNERSHIP ACQUISITION BY CONTRACT IN CIVIL LAW COUNTRIES}

Rules on acquisition of ownership by means of contract concluded with the existing owner are usually classified in three broad categories. What all three have in common is the requirement that the person conveying the ownership is indeed the owner, i.e. that the ownership is actually being transferred by the current owner to the new owner. Exceptions to this rule exist (acquisition a non domino, acquisitive prescription or usucapio, acquisition by reliance onland registry) but are considered outside of the 'acquisition by contract' scenario.

The first (and the oldest) is the concept that requires both iustus titulus, a contract or other legal act aiming at transfer of ownership, and modus acquirendi, the mode of the transfer itself. Not denying Roman law origins of such concept, it will be examined here from the point of view of the Austrian law, for several reasons: ABGB, Austrian codification, is one of the oldest codifications that still survives; Austrian civil law (especially property law) exerted greatest influence on civil (property) law in Serbia and Austrian system of registration of real property was the role model and the starting point for the Serbian real property registration system. The idea behind the said system is that the contract itself is merely a legal ground, iustus titulus for the acquisition of ownership, and that ownership is acquired, based on such contract, by a special act, called modus acquirendi or mode of acquisition in the strict sense. ${ }^{2}$ The

L. Marković, Građansko pravo I, Opšti deo i Stvarno pravo [Civil Law I - General Part and Property Law], Beograd 1927², 353-356, 370 et seq.

2 See for Austrian law, chronologically E. Demelius, Grundriß des Sachenrechts, Leipzig 1900, 24; J. Krainz, L. Pfaff, A. Ehrenzweig, System des österreichischen allgemeinen Privatrechts, Band I Der allgemeine Teil und das Sachenrecht, Wien 19135, 135 137, 581 et seq., 624-626; A. Ehrenzweig, System des österreichischen allgemeinen Privatrechts, Band I, Zweite Hälfte: Das Sachenrecht, Wien 1923, 196 et seq., 253-254; H. Klang in H. Klang (Hrsg.), Kommentar zum Allgemeinen bürgerlichen Gesetzbuch, Erster band Zweiter Halbband, Wien 1931, 151-152; F. Gschnizer, Sachenrecht, Wien 1968, 90-94; F. Gschnizer, Österreichisches Sachenrecht, Wien 1985², 99-104; H. Koziol, R. 
purpose of the modus is to make the conveyance public (visible to others), therefore the modus is required with third parties in mind. The contract, as legal ground (Rechtsgrund, Titel) creates merely an obligation to convey the ownership, but the conveyance itself is carried out through a different act, modus acquirendi (delivery in respect of movables, ${ }^{3}$ registration in respect of immovable property). Both titulus and modus are required for the transfer of ownership. Otherwise, if the legal ground, e.g. a sale contract, is void or avoided, there would be no valid acquisition despite registration. In other words, registration without a valid legal ground is itself invalid (but even such erroneous registration may have some consequences, in case of acquisition by reliance). The significance of the delivery (transfer of possession) for acquisition of real property by contract, irrespective of it not being the modus in that case, evolved in Austrian law. Older doctrine first refused to recognize any significance thereof (save for the case of fraud) ${ }^{4}$ but later recognized its significance in case of multiple disposal of the same real property by one person. ${ }^{5}$ The idea was that, in case the owner sold and transferred possession to an acquirer, the second acquirer who derives the ownership from the same transferor is in bad faith and thus cannot acquire ownership. More recent doctrine and case law, however, seem to reaffirm the principle of acquisition by filing (registration), reducing the significance of the transfer of possession. ${ }^{6}$ Therefore, in contemporary Austrian law, in case of multiple transfer of ownership of real property by one transferor, the transfer of

Welser, Grundriß des bürgerlichen Rechts, Band II, Wien $1996^{10}, 62,74-78$, A. Kletečka in H. Koziol, R. Welser, Bürgerliches Recht, Wien 2006 ${ }^{13}, 310-311,325-329$; G. Iro, Bürgerliches Recht, Band IV Sachenrecht, Wien $2010^{4}, 129$ et seq.

3 The legal qualification of delivery was changed in Austrian law under German doctrinal influence. See H. Koziol, R. Welser (1996), 63, 75.

4 See for a good overview of doctrinal dispute and case law at the beginning of the $20^{\text {th }}$ century J. Krainz, L. Pfaff, A. Ehrenzweig, 630-636; slightly updated in A. Ehrenzweig, 258-265. Only in case of fraud would the registered owner have a weaker right than prior non-registered acquirer who obtained possession.

5 See an exhaustive overview of doctrine and case law in H. Klang in H. Klang (Hrsg.), 202-206. Klang proposed his solution at 206-207. If the registered acquirer knew or ought to have known of the prior contract followed by the delivery to the prior acquirer, he is in bad faith and cannot acquire ownership by registration. Knowledge of the existence of the prior contract is irrelevant, if no delivery took place pursuant to that contract. This position is followed by F. Gschnizer (1968), 96, who claimed that the case law followed the solution proposed by Klang.

6 Already in the second edition of the Gschnizer's work, prepared by Faistenberger, Barta, Call und Eccher, the change of position was noticed. See F. Gschnizer (1985), 106-107. However, transfer of possession was still significant for acquisition of ownership in multiple disposal scenario, but to a lesser extent. Further change is reflected in H. Koziol, R. Welser (1996), 76 fn. 63. The position would read as follows: the first acquirer who obtained possession should be protected by damages claim, but the ownership should rest with the acquirer who requested registration first. It seems that, with some 
possession of real property may only lead to liability for damages of the subsequent registered owner (if he knew or ought to have known for prior transfer of possession), and not to the challenge of the principle of acquisition by registration. This meandering of Austrian doctrine and case law is partly attributable to the fact that the territory of Austria changed over the century, and that contemporary position is adequate for the orderly kept land registries (and they are indeed kept so in todays Austria), whereas the position that recognized the significance of delivery was more adequate for cases and territories where land registries were not so orderly kept. ${ }^{7}$ In conclusion, the Austrian system is based upon differentiating the moment the contract aiming at ownership transfer is formed from the moment of acquisition of ownership by a different act, the modus, which in case of real property is registration, whereas the validity of the underlying contract is a condition for the acquisition based on delivery, respectively registration (as modus-es).

The second category, that is typical for French law, does not differentiate the moment of conclusion of contract from the moment of conveying the ownership - ownership is conveyed directly by contract, which has an effet translatif. "To sell is to alienate", reads the maxim in French law, ${ }^{9}$ which is explained by the fact that the contract on conveyance is executed in the moment it is formed. The roots of this rule are historical, and have to do with the pre-code practices in France in application of a different, Roman law system. ${ }^{10}$ Theoretically, the principle is often attached to the recognition of the principle of autonomy of will (autonomie de la volonté) to the greatest extent possible, and also to the concept of will as the prevailing factor in private law. ${ }^{11}$ The doctrine has also explained it by the principle of opposability of contracts against third parties in French law, which is self-explanatory in case the subject-matter of contract is conveyance of ownership or other in rem right, but also applies in cases of other contracts. ${ }^{12}$ There are some exceptions to this "conveyanc-

exceptions, that position was adopted by recent case law, from the 1990 s onwards. See A. Kletečka in H. Koziol, R. Welser (2006), 327 fn. 81 in fine; G. Iro, 132, fn. 34.

7 Klang explicitly mentioned Galizia and Bukowina in that respect.

8 See instead of many G. Ripert, J. Boulanger, Traité de droit civil, d'après le traité de Planiol, Tome II, Obligations-Droits Réels, Paris 1957, 854. "Il [le contrat] est translatif de propriété" (emphasis in original text). See Art. 1138 CC, as well as Arts. 1583 and 938.

9 Ibid. "Vendre, c'est aliéner".

10 See Frédéric Zénati, Les biens, Paris 1988, 152; G. Ripert, J. Boulanger, 855. The use of clause de dessaisine-saisine and traditio ficta led to the requirement of modus acquirendi of Roman law becoming obsolete in practice.

11 G. Ripert, J. Boulanger, 858.

12 See Alfred Rieg, Le role de la volonté dans l'acte juridique en droit civil français et allemande, Paris 1961, 489. Rieg also constitutes a specific class of legal acts 
ing" effect of the contract between the parties in French law: first, the subject-matter of the conveyance must be specified, because one can only own a specified property, second, if the subject matter is a 'future property' than the conveyance takes part only after it is created, and third, the parties may deviate from the rule in their contract themselves. ${ }^{13}$ However, and more importantly, given the fact that ownership as an absolute right is opposable against any third party, it should be supplied with publicity, because in that way third parties can be aware of the right they need to recognise and honour. Therefore the effet translatif of a contract in French law is limited in respect of the rights of the third parties, and in this point the rules pertaining to movable and immovable property begin to deviate. For the purpose of this paper, only the regulation of the real (immovable) property will be presented. The original Code civil of 1804 did not require publicity for transfer of ownership of real property, apart in case of the contract of donation, which needed to be transcripted, i.e. registered in order to be opposable against third parties. ${ }^{14}$ Registration was introduced in March 1855 in the area of the law of hypothec (loi sur le transcription en matière hypothécaire), which was required for developing the crédit foncier, and that system was modified in October 1935. The current system of publicité foncière was introduced on 4 January, respectively 14 October 1955, by virtue of a thorough reform of Code civil rules, and the idea was to make all disposals of real property public. The effect was that the acts on conveyance of real property now required form of authentication in order to be registered, and registration is a condition for the opposability of the contract (and ownership acquired thereupon) against third parties. Under Art. 28 of the 1955 Act, all acts of changes of ownership of real property must be publicized, ${ }^{15}$ and if it is not the case, under Art. 30-1, such act is inopposable aux tiers, so cannot be opposed to third parties who acquired and registered a right upon the same immovable. ${ }^{16}$ Between two acquirers of ownership of the same real property, the one who was the first to publicize his act on conveyance shall prevail. The older doctrine and case law made an exception to this rule only in case of fraud. ${ }^{17}$ Good faith on part of the second acquirer, who entered into contract later but registered first, is not required. So, irrespective of whether the second acquirer actually knew about the first con-

as ' 1 'acte translatif', the subject-matter of which is conveyance of a right. See. A. Rieg, 424.

13 G. Ripert, J. Boulanger, 859-860.

14 Art. 939 CC, based upon a rule of an Ordinance from august 1539.

15 See on that in detail J. Ghestin, C. Jamin, M. Billiau, Traité de droit civil, Les effets du contrat, Paris $2001^{3}, 855$.

16 Ibid., 871 et seq., especially 872.

17 G. Ripert, J. Boulanger, 863. 
tract or ought to have known about it under the circumstances, he shall become the owner if he registers first, save in the case of fraud. This is in contrast to the rules on movables, where good faith is required on the part of the later acquirer whom the transferor delivered the possession first. ${ }^{18}$ Thus not much is left of the effet translatif of a contract in case of real property, given the significance of publication, at least from the practical point of view. Theoretically, though, the difference remains, because the contract, which is valid even without registration, conveys the ownership, and only its opposability against third parties depends on its registration. In practice, the contracts and all the formalities related to ownership transfer in respect of real property are handled by notaries, who take good care that such contracts are registered immediately after formation. Therefore it is fair to conclude that, in French law, the contract conveys the ownership only between the parties, and that registration (inscription) is required for it to produce contra omnes effect.

Last but not least, the third category of rules on acquiring ownership by contract with the existing owner, attached primarily to German law, is the system upon which the ownership is transferred by a special kind of legal act, so-called legal act of disposition (Verfügungsgeschäft), which comes as an act of fulfilment of the contract by which the transferor undertook the obligation to convey the ownership, the legal act of obligation (Verpflichtungsgeschäft), irrespective of the validity of the latter. Attempting to translate this into the language of the titulus/modus system, one could say that the modus, understood as a legal act (contract) of disposition, transfers the ownership, irrespective of the validity of the titulus. ${ }^{19}$ The system rests on two basic principles, the principle of differentiation or separation (Trennungsprinzip), under which the contract aimed at conveying ownership ('Verpflichtungsgeschäft') and the contract that conveys it ('Verfügungsgeschäft') are differentiated, and the principle of abstraction (Abstraktionsprinzip), under which the validity of the conveyance contract, the 'Verfügungsgeschäft', is independent from the validity (and existence, for that matter) of the obligation contract, the 'Verpflichtungsgeschäft'. ${ }^{20}$ Doctrinally speaking, German law sees the

18 Art. 1141 CC. G. Ripert, J. Boulanger, 861.

19 One needs to be careful, though, for this "translation" often leads lawyers who are not directly involved with German doctrine to misunderstand their system.

20 See on historical origins of this system S. Buchholz, Abstraktionsprinzip und Immobiliarrecht, Frankfurt a.M. 1978, 1 et seq. See also M. Wolff, L. Raiser, Sachenrecht, Tübingen $1957^{10}, 211$ et seq. (for immovable property), 233 et seq. (for movables); K. H. Schwab, H. Prütting, Sachenrecht, München $2006^{32}$, 137 et seq. (for immovable property), 144 et seq. (for movables); J. Baur, R. Stürner, Sachenrecht, München 2009 ${ }^{18}$, 284 et seq. (for immovable property), 635 et seq. (for movables); H. P. Westermann, K. H. Gursky, D. Eickmann, Sachenrecht, Heidelberg $2011^{8}$, 634 et seq. (for immovable property), 305 et seq. (for movables). As of most recent papers see Michael Martinek, "Kollegiale Reflexionen zur Didaktik des Abstraktionsprinzips - Wie lehren wir es und was lehrt es 
delivery, respectively the Auflassung (a special declaration enabling the conveyance of real property by registration), itself as a contract (legal act, Rechtsgeschäft), based upon which the ownership is conveyed (or, in case of real property, which enables conveyance by registration). So, there are two contracts, the one that forms the legal ground for conveyance, e.g. sale contract, and the other that conveys ownership in the narrower sense, and that is delivery (for movables) and the Auflassung (for immovable property), as the act required for registration. The effect of the first contract is an obligation of the transferor to enter into the second contract and thus convey ownership, and the effect of the second is the conveyance of ownership itself. Behind the meticulous doctrinal development and analysis, originally carried out by C. F. von Savigny, lies a system which, quite pragmatically, aims at an increased security of legal transactions in business practice. Namely, in German law, the effects of rescission or invalidity of a contract that was used as the Verpflichtungsgeschäft take place only between the parties to that contract, without touching the issue of ownership conveyance, because ownership is conveyed by the other legal act, the Verfügungsgeschäft, the validity of which is independent from the validity of the underlying contract (abstraction principle). This overcomes the weak point of the titulus-modus system, which lies in the fact that the failure of the right of a predecessor carries with it the chain failures of ownership of all persons who acquired it against the faulty owner or his successors (the mentioned 'domino effect'). So, German law requires specific abstract agreement, with in rem effect for the conveyance of ownership, which they call dingliche Einigung (in case of real property, Auflassung). If the Verpflichtungsgeschäft fails, the dingliche Einigung can still produce its (conveying) effect, and the transferee may in that case request the "alienated" property back from the other party only as a creditor, not as an owner. ${ }^{21} \mathrm{He}$ can get the property back, provided the acquirer still has it in its' possession. If that is not the case, the acquirer may be liable for the value of the property and for damages, but the ownership stays as it is, with the successor of the acquirer.

\section{SYSTEM OF ACQUISITION OF OWNERSHIP OF REAL PROPERTY BY CONTRACT IN SERBIA AND DEPARTURES THEREFROM}

Rules on acquisition of ownership in Serbian law (including acquisition by contract with the previous owner) are contained in the 1980 Law on Basic Ownership Relations (Zakon o osnovnim svojinsko-pravnim od-

uns?”, in Jürgen Stamm (Hrsg.), Festschrift für Helmut Rüßmann, Saarbrücken 2012, 95 et seq.

21 Based upon the rules on condictio sine causa (unjust enrichment). 
nosima, hereinafter: ZOSPO). ${ }^{22},{ }^{23}$ In the area of regulation of matters of acquisition of ownership on the ground of a contract with previous owner, the Serbian law, traditionally, adopts as a model the solution of the Austrian law ( $\$ 380$ of the 1811 Austrian Civil Code - ABGB), providing that the right may be acquired from the predecessor who is the owner, if two requirements are fulfilled - i.e., that there exists a fully valid contract aimed at the conveyance of ownership (iustus titulus), that there is the act of handing over (delivery), for movable objects, and/or the act of filing the right into land books or the transfer of a title deed, for immovable property (modus acquirendi). Although already in the first half of the twentieth century there were viewpoints that this relatively conservative way of regulation of acquiring the right of ownership on the ground of a contract with previous owner should be abandoned in favour of the German system based on the principle of abstraction, ${ }^{24}$ one might conclude that the titulus/modus system presented above is generally accepted at present, at least in the doctrine and the general legislation on property law. ${ }^{25},{ }^{26}$ One of the most serious shortcomings of the system accepted in Serbian law is the mentioned 'domino effect'. ${ }^{27}$

22 Official gazette of the Socialist Federal Republic of Yugoslavia Nos. 6/1980 and 36/1990, Official gazette of the Federal Republic of Yugoslavia No. 29/1996, Official gazette of the Republic of Serbia No. 115/2005 (other statute).

23 Some of the means of acquisition are not regulated in the ZOSPO but elsewhere. See comprehensively with explanations M. Živković, "Acquisition of Right of Property" in Property Law Amendments in Serbia, Belgrade 2004, 83 et seq.

24 See L. Marković, 335-336.

25 Draft Property Code from 2012, available at http://www.ius.bg.ac.rs/prof/Materijali/xivmil/NACRT\%20ZAKONIKA\%20O\%20SVOJINI.pdf, last visited on April 6, 2015, has retained this system, see Arts. 87-90. This text, however, is not likely to become a statute, so it only reflects the opinions of the expert group that drafted it. The expert group preparing the Draft Civil Code has not yet published the part of the draft pertaining to property law, but as far as I am informed, the titulus/modus system shall be retained in this draft as well.

26 A good part of case law also follows this traditional line. See Decision of the Higher Commercial Court, Pž. 2010/2008(3) dated 8 May 2008, Sudska praksa trgovinskih sudova - Bilten [Case Law of Commercial Courts, Bulletin] No. 4/2008 (both iustus titulus and modus acquirendi required for acquiring ownership); Decision of the Supreme Court of Cassation, Rev. 385/2010(1) dated 30 June 2010 (contract without registration cannot lead to acquisition of ownership); Decision of the Commercial Appellate Court, Pž. 2739/2010 dated 20 October 2010 (registration without the valid contract, as well as contract without registration, are insufficient for acquisition of ownership), all available in database Paragraf Lex.

27 See Decision of the Commercial Appellate Court, Pž. 6835/2010(1) dated 14 April 2010 (if the contract upon which the seller acquired his ownership is void, the ownership of the buyer falls, and the sale contract is also void); Decision of the Commercial Appellate Court, Pž. 8186/2014 dated 21 August 2014 (the successor in law cannot acquire nor transfer to other more rights than what his predecessor in law actually had), all available in database Paragraf Lex. It is interesting to note that there is almost a unison 
As far as immovable property is concerned, ZOSPO includes only one entirely lapidary rule relating to the acquisition of ownership: "On the ground of a legal transaction, the right of ownership regarding an immovable object shall be acquired by means of filing it into a public book, or in some other way as specified by statute" (Article 33). Having in mind the state of affairs in the sphere of registers of real property, the expression "a public book" mentioned in the legislative text now in most cases means real estate cadastre but can still encompass land books in some cases, while the expression "some other way as specified by statute" refers to the title deed transfer in the areas where the title deed system still exists. ${ }^{28}$ Also, given the significant number of unregistered real property that still exist in Serbia, the case law developed a rule that payment of purchase price and transfer of possession also qualify as "some other way as specified by statute" in respect of such properties, while admittedly there is no statute providing such rule. ${ }^{29} \mathrm{ZOSPO}$ does not contain a provision regarding the situation of several persons concluding particular legal transactions for the purpose of acquiring ownership over the same immovable object. ${ }^{30}$ In respect of movables, ZOSPO contains a rule relating to such case, in which the primacy of right shall be with that acquirer to whom the object has been originally handed over. ${ }^{31}$ According to a standpoint defended in the doctrine, that rule shall be applied only on condition that the acquirer to whom the object has been originally handed over acted in good faith, meaning that he has behaved like this if he was not aware or, according to the circumstances of the case, could not have been aware of the fact that the conveyor has previously concluded a con-

position of the courts that if the transferor is not the owner, the contract on transfer of ownership is null and void, a conclusion drawn by invoking the rule on forbidden contracts. Without analyzing this here in more detail, I stress that I hold such position completely erroneous.

28 See overview of real property registration systems in Serbia M. Živković, "Real Estate Registers" in Property Law Amendments in Serbia, Belgrade 2004, 103 et seq.

29 See Decision of the Commercial Appellate Court, Pž. 7975/2013(2) dated 2. October 2014 (proof of payment of purchase price and of possession can replace registration as modus acquirendi); Decision of the Commercial Appellate Court, Pž. 8712/2013(2) dated 13. November 2014 (for unregistered real property, price payment and transfer of possession are modus acquirendi), all available in database Paragraf Lex.

30 Consequently, there was no counterpart to $\$ 440$ of the Austrian Civil Code, which was applicable in some areas of the former SFR of Yugoslavia as a "legal rule" (soft law), and according to which the priority has been with that acquirer who was the first to request the registration (while the theory used to be divided regarding the issue of the good faith requirement and significance of delivery, as explained above).

31 See Article 35 of the ZOSPO. It should be noted in this respect that, according to the 1978 draft of that Act, this Article has expressly included the additional wording saying "regardless of good faith" of the acquirer; that additional wording, however, did not find its place in the final text. 
tract with another person. ${ }^{32}$ To a certain extent this shifts the moment of acquisition of movables towards the formation of contract aimed at conveyance of ownership, which is typical for French system as explained above. Along the same lines, handing over of immovable into possession has, under the law, no relevance at all for conveying the right of ownership (apart that it may lead to acquisition by means of acquisitive prescription). ${ }^{33}$

Courts have, however, faced considerable difficulties in the application of this provision, particularly after the records of real property became disorderly kept in the second part of the last century. This has additionally weakened the effect of the principle of (acquisition by) filing (registration). Case law therefore started to depart from the rule that ownership of real property is acquired upon a contract by registration, and became inconsistent. Thus, the following Conclusion was adopted at the joint session of civil and civil-commercial chambers of the Federal Court, republic and provincial supreme courts, and the Supreme Military Court, held on 28 and 29 May 1987 in Belgrade: $:^{34}$ "(1) Where several persons have concluded particular legal transactions with the purpose of acquiring the right of property regarding one and the same immovable object, the court shall decide as to a predominant right by applying the principle of morality of the socialist, self-managing society, good faith and honesty, and the principle of prohibition of the misuse of law. If all the buyers acted in good faith and if the immovable property was not handed over to any of them, and if no one of them has effected the entry into the land books or another public records, the predominant right shall pertain to the earlier buyer. If all the buyers are in good faith, the predominant legal ground pertains to a buyer who did effect the entry into the land books or another public records, and if no one of them has effected the entry into the land books or another public records, the predominant right shall pertain to a buyer to whom the immovable object has been handed over in possession. This shall be the case also where a seller has handed over in possession the immovable object to a subsequent buyer who did not act in good faith, or if a buyer who did not act in good faith was successful in making an entry in the land books or an another public records. (2) In a litigation for the purpose of determining a predominant legal ground,

32 See O. Stanković, M. Orlić, 66. Stanković refers to the change of final edition of the statutory text, mentioned in the preceding footnote.

33 This is apart from the role that the case law attributed to it, which was already mentioned and shall be further presented and analyzed.

34 See Bilten sudske prakse VSS [Court Practice Bulletin of the VSS], 3/1987, 5. On the development of case law and doctrine in former Yugoslavia that led to this Conclusion see Meliha Povlakić, Transformacija stvarnog prava u Bosni i Hercegovini [Transformation of Property Law in Bosnia and Herzegowina], Sarajevo 2009, 125 et seq. 
the capacity to be sued shall pertain to the seller and to remaining buyers of the same immovable property, as unitary co-litigants."

Given that this Conclusion is still binding for judges of the civil chambers of the highest courts in the country (specifically, the rule is still binding for the Supreme Court of Cassation), it is rather close to a statutory rule, so that judges of lower-instance courts, too, adhere to it (although it is not formally binding for them). ${ }^{35}$ Recent court decisions demonstrate that this Conclusion is still quite vital in Serbian case law, ${ }^{36}$ despite the fact that the new registry (the real estate cadastre) is relatively up to date, given the significant investments made during the last decade. It should also be noted that under this Conclusion existence of good faith is assessed according to the need that the acquirer must not be aware of the existence of an earlier contract, nor that he should have been aware of it. ${ }^{37}$ Consequently, it will not suffice if the acquirer only verifies the situation in the registry, or even demonstrates that he had checked the situation regarding the possession, because it is possible to prove that, although he has performed both checks, he still had been aware of the existence of an earlier contract, or should have been aware of it - which makes him considered to be in bad faith (mala fide) and with a weaker right as compared to the previous acquirer who has acted in good faith. In such a way the principle of acquisition by filing (registration) regarding the land books and real estate cadastre is de facto entirely derogated. On the other hand, the significance of the formation of contract on conveyance is yet again stressed, for the acquirer who was the first to conclude the contract shall always be held in good faith, and if the subsequent acquirers were in bad faith, i.e. if they knew or ought to have known for his contract, he shall prevail in obtaining ownership even against the registered owner. Two recent decisions demonstrate position of the courts in this respect in

35 On the binding character of standpoints of principle of the highest court, see V. Vodinelić, Građansko pravo - Uvod u građansko pravo i Opšti deo građanskog prava [Civil Law - Introduction to Civil Law and General Part of Civil Law], Beograd 2012, $117-120$.

36 See Decision of the Supreme Court of Serbia, Rev. 1/2004 dated 19 April 2005 (good faith principle decisive in case of multiple alienation, and irrelevant outside that scenario); Decision of the Higher Commercial Court, Pž. 9360/2006 dated 30 January 2007 (possession decisive when both acquirers from the same transferor are in good faith); Decision of the Higher Commercial Court, Pž. 2010/2008(1) dated 8 May 2008, Sudska praksa trgovinskih sudova - Bilten [Case Law of Commercial Courts, Bulletin], No. 4/2008 (among the acquirers in good faith, the one having possession prevails); Decision of the Supreme Court of Cassation, Rev. 1177/2010 dated 8 July 2010 (awareness of the existence of the previous contract, even if it is formally inadequate but apt for convalescence, renders the subsequent acquirer in bad faith), all available in database Paragraf Lex. It is clear that all of these decisions utilize the wording of the 1986 Conclusion.

37 See O. Stanković. M. Orlić, 335-336, and the case law presented there, particularly in fn. 1142. Orlić was correct to recognize inclination towards the French system in respect of this point. 
a way that can be used as a model. The first is the Decision of the Appellate Court in Belgrade, Gž. 7114/2013 dated 13 June 2014. ${ }^{38}$ The court found that the buyer of real property must have known for the existence of an earlier contract on disposition by the same real property, because that (second) byer installed bullet-proof entrance doors in a flat and attached the contract to that door. ${ }^{39}$ Even though the Court found that the possession of the flat was first transferred to the first buyer, it is clear that the second buyer was the one who installed the bullet-proof doors, so was in actual possession of the flat. Therefore, the first buyer actually had only the contract, without possession, and the second had a contract with possession, and the court reasoned that, by formation of the first contract, the seller lost the ownership and the possibility to convey it to another acquirer subsequently. The second decision does not deal with transfer of ownership, but reflects the same line of thinking - that the formation of contract on ownership transfer means that the transferor is no longer the owner. It is the Decision of Commercial Appellate Court, Pž. 3047/14 dated 20 June 2014, ${ }^{40}$ which had to do with establishing of hypothec by a registered owner of real property who had previously concluded a contract on sale of the same real property. The Court decided that: "Hypothecary declaration made after the sale of the encumbered real property is null and void, irrespective of the fact that the person giving such declaration was, at the moment of its creation, registered owner of such real property". This decision also rests on the idea that mere existence of contract aimed at transfer of ownership of real property deprives the transferor from ownership and makes him unable to dispose of the real property by a subsequent legal transaction. It also completely destroys the principles of land registration law, such as acquisition by filing and reliance.

One statutory provision in special legislation also seems to have shifted Serbian law towards the model inspired by the French system: it is Article 4a of the 1998 Law on Transfer of Immovable Property ${ }^{41}$ (ZPN 1998), adopted by amendments made in 2009, which lasted until new Law on Transfer of Immovable Property came into force on 1 September 2014 (ZPN 2014). ${ }^{42}$ The 2009 amendments to $1998 \mathrm{ZPN}$ introduced territorial competence for court verification of signatures affixed to contract on transfer of immovable property. These amendments have also forbidden the court to verify signatures on the second contract related to the same real property if the conveyer is the same person. Court verification

\footnotetext{
38 Available in database Paragraf Lex.

39 It seems the court found that these were evidence that the second buyer doubted something is wrong, and there is another pretender to ownership of the same flat.

40 See Bilten sudske prakse privrednih sudova [Bulletin of Case Law of Commercial Courts] No. 1/2015. 48-50.

41 Official gazette of RS Nos. 42/1998, 42/2009.

42 Official gazette of RS Nos. 93/2014, 121/2014 and 6/2015.
} 
was a condition for validity of contracts on transfer of ownership over real property (now the notarial deed or notarial solemnization is required). Therefore the ban on court verification of subsequent contract, in fact, meant that one owner can conclude only one contract on transfer of his ownership over real property, for court verification of signatures is forma ad solemnitatem for such contracts. This was introduced, along with the appropriate software at the verification desks in courts, in order to avoid the situations of multiple alienations, which were more frequent than it could be tolerated, especially related to apartments that are under construction. This provision clearly does not adhere to the titulus-modus system, and thus its adherence to the Constitution may be challenged. This provision effectively revokes the power of owner to dispose of his property, if he already concluded one contract to that aim. Namely, the seller (or other transferor) remains the owner even after the sales contract is concluded, until the new owner is registered, and thus, as such, he should be able to conclude another contract to sell the same property. This has been made practically impossible by Article 4a of the ZPN 1998, and if the buyer from the concluded contract abandons it for some reason, the seller would have to either contractually rescind it or sue the buyer for rescission at the competent court of law, in order to be able to dispose of it again. ${ }^{43}$ This really resembled the system in which the titulus i.e. the contract itself conveys ownership, without the need of any modus whatsoever. It seems the legislator realized that it had gone too far, and in the new ZPN 2014 the rules changed. While the registry of contracts on transfer and the territorial competence, now of public notaries, was kept, the ban on creating or verifying a second contract by the same transferor was abandoned, and public notary just has the duty to warn the parties that the database shows that there is a prior contract in respect of the same real property by the same transferor (seller). ${ }^{44}$

\section{CONCLUSION}

It is difficult to label the above presented set of positive law rules in Serbia as coherent. The Romanic system of titulus and modus is merely a starting point thereof. On the one hand, it seems that the registration is constitutive and that ownership cannot be acquired by virtue of contract if there was no registration, at least in respect of registered real property. On the other hand, case law and court practice, as well as some newer legislation, seem to be inspired by a different system, under which the

43 In more details on this see M. Živković, "O kvalitetu novijih građanskopravnih propisa u Srbiji [On the Quality of Newer Civil-Law Legislation in Serbia]", in Pravni zapisi [Legal Records] No. 1/2010, 129-132.

44 See Art. 4b ZPN 2014. 
contract itself conveys ownership, or at least in which the transfer of possession is quite relevant. While it is true that the courts departed from the system of acquisition by registration because of the poor state of the existing registries, it is also true that current position of case law is not apt to stimulate and promote an orderly keeping of real property registry. As a result, the current situation in respect of acquisition of ownership of real property by contract (considered integrally it cannot be called a system, in my opinion) does not provide an effective basis for the realisation of legal certainty in an otherwise exceptionally significant area of trade in immovable property. The departures from the traditional system, irrespective of how the reality required it at the time they were made, are now a liability that renders the real property trade uncertain. Mixing the systems in an incoherent way, so that sometimes sale contract suffices for ownership, sometimes delivery (possession) is required and sometimes also registration cannot lead to satisfactory outcome. Moreover, Serbian case law seems to go even a step further from its' French role model: in France a contract transfers the ownership of real property only inter partes, and registration is a condition for opposability against third parties, and in some Serbian court decisions it seems that the court found that the contract transfers the ownership fully, erga omnes.

I think that the approach that would apply a chosen system consistently has the best chances for success. Given that Serbia for reasons of tradition chose the titulus-modus system, it should be applied consistently, so registration should be required for acquisition of ownership by contract with the previous owner. In case of multiple transfers, the acquirer who requested registration first should have precedence over others, irrespective of who has prior contract or, eventually, possession, i.e. irrespective of his good or bad faith. The knowledge of a prior contract aimed at the transfer could be the ground for an obligation to compensate damages to an earlier acquirer jointly and severally with the transferor, but should be completely irrelevant for the issue of who acquires ownership - it is acquired by the person who registered based upon valid contract with previous owner. This solution, which means a consistent application of the principle of filing (registration), would from its part contribute to the orderly keeping of the real property registry, which would justify the huge investments made into reform and data update thereof. As for the non-registered properties, delivery (possession transfer) could be recognized as modus acquirendi until some sort of records of a more tangible nature is made (say, the collection of transfer documents, where the modus would be depositing a copy of the transfer document in such registry, as is the case in Austria ${ }^{45}$ ).

It seems that the confusion and antinomies in current case law makes it impossible to remedy the situation without adoption of the new

45 See A. Ehrenzweig, 234. 
codification, i.e. a new set of statutory rules, which should not leave too many issues unregulated, at least in this very sensitive and significant area. Introduction of notaries in Serbia in $2014,{ }^{46}$ only exposed the shortcomings of the existing situation and reiterated the need for codification of property law, which should remedy this situation in the future. Related to the issue at hand, it seems that the solution contained in the Draft Property Code of 2012 represents a good starting point for developing effective rules on real property ownership acquisition by contract. In case of multiple transfers of real property, Art. 90 of said Draft provides that the acquirer who registered first shall obtain ownership, provided however that he could not have known for the earlier disposition based upon data contained in the registry. Therefore even if the acquirer knows about the prior contract, or that a prior buyer is in possession, he is considered to be in good faith if the data in the registry, at the moment of his applying for registration, have not contained info on such prior contract and/or possession. This rule would also reaffirm the role of the registry and indirectly contribute to its orderly maintenance.

46 The Law on Notaries Public was introduced in May 2011, and it started to be applied as of 1 September 2014. 